\title{
The Relationship of Visits to Posyandu with the Nutrition Status of Toddlers in Amplas Health Center
}

\author{
Namora Lumongga ${ }^{1}$, Etti Sudaryati ${ }^{2}$, Donna Theresia ${ }^{3}$ \\ 1,2,3 Faculty of Public Health, Universitas Sumatera Utara, Indonesia \\ donnatheresia01@gmail.com
}

\begin{abstract}
Weighing the child's weight every month to find out the nutritional status of children is one of the routine activities at the Posyandu. One effort to reduce the problem of malnutrition in children is to increase the participation of mothers in visiting and weighing their children to the Posyandu every month. This study aims to determine the relationship of the number of Posyandu visits with the nutritional status of children under five (1-5 years). This study uses a descriptive correlation design with a retrospective approach. The study was conducted in the working area of the Amplas Health Center with a sample of 382 mothers and children under five years old using proportional random sampling technique based on the number of Posyandu. The measuring instrument used was a questionnaire for demographic data and a child's weight-weighing registration book. The analysis used is univariate analysis to determine the frequency distribution and bivariate analysis using chi-square. The results showed that 145 people (38\%) regularly visited Posyandu and 237 people (62\%) did not regularly visit Posyandu. Children who have good nutritional status are 203 people (53.1\%), malnutrition is 109 people $(28.5 \%)$, and malnutrition is 70 people $(18.3 \%)$. The bivariate analysis results obtained $p$ value $(0.00)<a(0.05)$, so it can be concluded that there is a correlation between the number of Posyandu visits and the nutritional status of children under five. Suggestions for puskesmas staff to be able to conduct training and health education to cadres and improve health facilities in Posyandu.
\end{abstract}

Keywords

toddler, mother, posyandu, nutritional status

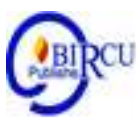

\section{Introduction}

It is very important to monitor toddlers' growth to find out early growth faltering. Weighing every month is very necessary to know this. Growth and development in infants can be monitored through weighing children every month.

Weighing fewer than five can be done in various places such as posyandu, polindes, puskesmas or other health service facilities. Posyandu is assumed as one of the right approaches to reduce infant mortality and morbidity and can improve the nutritional status of toddlers. The weighing activity is one of the main activities of the posyandu and as one of the community nutrition improvement programs. Weighing fewer than five is intended to monitor its growth every month. Weighing fewer than five is important to be carried out every month to five years at the posyandu to find out the growth and development of toddlers.

Coverage of under-fives weighing can be measured by the frequency of under-fives visits to weigh regularly on the last six months. Ningsih et al (2019) states that there is a relationship between children under five who are weighed with poor and malnourished 
status, infants who are weighed irregularly have a risk of 1.5 times experiencing growth failure compared to those who are regularly weighed.

World Health Organization (WHO) in 2018 estimated that there were 51 million children under five experiencing nutritional problems. Toddler deaths due to nutritional problems of 2.8 million people. The highest nutritional problems occur in African and Asian countries, including Indonesia. The results of the Indonesian Demographic and Health Survey (IDHS) show that IMR has decreased significantly from 68 deaths per 1,000 live births in 1991 to 1991, to 24 deaths per 1,000 live births in 2017.

One of the targets of the 2015-2019 National Medium-Term Development Plan (RPJMN) is to decrease the prevalence of malnutrition in children under five from 19.6 percent in 2013 to 17.0 percent in the 2015-2019 targets. Poor nutrition is also very closely related to stunting children, based on the 2013 Basic Health Research (Riskesdas) data, the national stunting incidence rate reached 37.2 percent. This figure has a different distribution between provinces. In some provinces the number of stunted children reaches 50 percent. That number continues to grow starting in 2010 at 35.6 percent.

The prevalence of malnutrition in North Sumatra by 22.4 percent is still included in the high category. Of the 33 districts/cities in North Sumatra, 17 districts/cities have a prevalence of malnutrition and are less than the provincial prevalence rate, which ranges from 22.6 percent in Serdang Bedagai Regency to 41.4 percent in Padang Lawas Regency. The highest prevalence of malnutrition and malnutrition is found in 3 (three) districts, namely Padang Lawas Regency at 41.4 percent, North Nias at 40.7 percent and West Nias at 37.5 percent. Whereas based on the 2015 MDG's target the prevalence of malnutrition and malnutrition in children under five is 15.5 percent.

This makes toddlers one of the most important Posyandu targets compared to other age children. When a child experiences malnutrition, it stunts the growth and development of the child, decreases endurance, and slows the formation of brain cells so that it affects the intelligence of the child.

Mothers' participation must be increased in an effort to reduce the problem of malnutrition in children by visiting and weighing their toddlers to Posyandu every month. This is reinforced by research Fallis (2013), about the relationship of family activity in Posyandu activities with the nutritional status of children under five, it was found that there was a significant relationship between family activity to Posyandu with nutritional status of children under five ( $\mathrm{p}$ value 0.00 ).

Wati research (2014), about the relationship between the activity of mothers visiting Posyandu and the development of nutritional status of children aged 6-23 months, found that the activity of maternal visits to Posyandu also affected the nutritional status of children ( $\mathrm{p}$ value 0.02 ).

The best toddler visits to Posyandu are routine every month or 12 times per year, visits 8 or more times in a period of one year are considered routine, and visits less than 8 times per year are considered non-routine (Dinas Kesehatan Jawa Tengah, 2013). Mothers who come to Posyandu will be given counseling related to maternal and child health by health workers from the Community Health Center, so as to increase the mother's understanding of the nutritional status, growth and development of her child ${ }^{15}$.

Mother's routine in visiting Posyandu will be very useful as monitoring body weight to determine the nutritional status of children by weighing each month so that they can detect early on the child's health status, so that further intervention can be determined immediately.. If the mother does not regularly visit the Posyandu, the nutritional status of the child is not monitored properly. 
Preliminary study conducted by researchers at Posyandu Mawar, in the working area of Amplas Health Center, Timbang Deli Sub-district on March 7, 2017, on 10 parents who brought their toddlers to Posyandu, 4 parents routinely visited Posyandu with their children's body weight increasing, and 6 parents not routinely visit Posyandu, the child's weight remains even decreased. The irregularity of visiting mothers who are less than 8 times a year to Posyandu, says because there is a rush at home, picking up children to school, forgetting the Posyandu schedule, children who refuse to be taken to Posyandu so that they cannot come to Posyandu. Based on the description above, researchers are interested in conducting research on the Relationship between the Number of Mothers Visit to Posyandu with Toddler Nutrition Status in Amplas Puskesmas Work Area.

\section{Research Methods}

This research was conducted in the working area of Medan's Amplas Health Center, which started from April to May 2020. This research is a type of quantitative research that uses a descriptive correlation research design with a retrospective approach. This design connects one variable with another variable, then tests it statistically (hypothesis testing) or known as the correlation test that produces a correlation coefficient.

The study population was all mothers and toddlers in the work area of the Amplas Health Center, totaling 15.322 toddlers. Sample calculation was obtained as many as 382 respondents and the sampling technique in this study was carried out by proportional random sampling based on the number of posyandu.

Data collection tools used in this study was observation sheets for respondent demographic data and registration books for toddlers' weight weighing records. Data analysis uses univariate analysis to describe the characteristics of the relevant respondents (mother's age, age of the child, sex of the child, mother's last education, mother's occupation, and family income in a month), the number of mothers visiting the Posyandu, and the nutritional status of children under five. Bivariate analysis to determine the relationship of the number of Posyandu visits with the nutritional status of children under five using the chi-square test.

\section{Result and Discussion}

\subsection{Results}

a. Univariate Analysis

Respondent characteristics such as mother's age, child age, child's sex, education, occupation and nutritional status of children are presented in table 1

Table 1. Distribution of Respondent Characteristics

\begin{tabular}{lcc}
\hline Characteristics & Amount & Percentage (\%) \\
\hline Mother's age (years) & 43 & 11.3 \\
$17-25$ & 327 & 85.6 \\
$26-35$ & 12 & 3.1 \\
$36-45$ & & \\
Age of child (month) & 114 & 29.8 \\
$12-24$ & 184 & 48.2 \\
$25-36$ & 52 & 13.6 \\
$37-48$ & 32 & 8.4 \\
$49-60$ & &
\end{tabular}


Gender (child)

Male

Girl

\section{Education}

Elementary school

Middle School

High school

Diploma

S1

Profession

Housewife

entrepreneur

Civil servants

\section{Nutritional status (BW /}

Age)

Good nutrition

Table 1 illustrates that the majority of mothers are in the 26-35 years range of 327 people $(85.6 \%)$. The majority of children respondents aged $25-36$ months were 184 people $(48.2 \%)$ with male sex as many as 204 people $(53.4 \%)$. The majority of respondents with a high school education are 325 people $(85.1 \%)$ with work status as housewives (IRT) of 255 people (66.75\%), with 203 children with good nutrition status (203 (53.1\%).

Table 2. Frequency Distribution of Visits to Posyandu

\begin{tabular}{lcc}
\hline Variable & Amount & Percentage (\%) \\
\hline Visit to Posyandu & & \\
\hline $\begin{array}{l}\text { Routine (visit } \geq 4 \text { times in } 6 \\
\text { months }\end{array}$ & 145 & 38.0 \\
\hline $\begin{array}{l}\text { Non-routine (visit }<4 \text { times in } 6 \\
\text { months) }\end{array}$ & 237 & $\mathbf{6 2 . 0}$ \\
\hline Total & 382 & $\mathbf{1 0 0}$ \\
\hline
\end{tabular}

Table 2, 237 people (62\%) did not bring their children to visit Posyandu and there were 145 people who regularly visited Posyandu (38\%).

\section{b. Bivariate Analysis}

Table 3. The relationship between Mother's Visit to Posyandu and the Nutritional Status of Children under Five

\begin{tabular}{lllll}
\hline \multirow{2}{*}{ Posyandu visits } & \multicolumn{2}{l}{ Nutritional status } & \\
\cline { 2 - 4 } & $\begin{array}{l}\text { Good } \\
\text { nutrition }\end{array}$ & Malnutrition & Malnutrition & Total P value \\
\cline { 3 - 4 } Routine & $\mathrm{n}(\%)$ & $\mathrm{g}(\%)$ & $\mathrm{n}(\%)$ & $\mathrm{n}(\%)$ \\
\cline { 2 - 5 } & $\begin{array}{l}100 \\
(69.0)\end{array}$ & $33(22.8)$ & $12(8,3)$ & $\begin{array}{l}145 \\
(100)\end{array}$ \\
\cline { 2 - 4 }
\end{tabular}




\begin{tabular}{lllll}
\cline { 2 - 4 } Not a routine & 103 & $76(32.1)$ & $58(24.5)$ & $\begin{array}{l}237 \\
(100)\end{array}$ \\
\multirow{4}{*}{ Total } & $(43.5)$ & & & 0.00 \\
& 203 & $109(28.5)$ & $70(18.3)$ & $\begin{array}{l}382 \\
(100)\end{array}$ \\
\hline
\end{tabular}

Table 3, respondents who routinely visited posyandu had good nutrition as many as 100 people $(69.0 \%)$ and respondents who did not routinely visit Posyandu had good nutrition as many as 103 people (43.5\%). Statistical test results obtained $p$ value $(0.00)<a(0.05)$, so it can be concluded that there is a relationship between the number of Posyandu visits with the nutritional status of children under five (1-5 years).

\subsection{Discussion}

\section{a. Characteristics of Respondents}

1. Age

The showed that the majority of respondents who visited Posyandu were 26-35 years old, 327 people (85.6\%) and the majority of children aged 25-36 months, 184 people (48.2\%). This is the same as the results of Busri's research (2017), regarding factors related to the behavior of visits to Posyandu in mothers of children under five, it was found that the majority of mothers who visited Posyandu were 26-35 years (63.4\%).

The age range of marriage for women suggested by the National Population and Family Planning Agency (BKKBN), (2017) ie at the age range of 20-25 years because at this age is biologically and psychologically mature and can think adults in building a household. Mothers will have their first child at the age of 23-30 years because at that age the risk experienced by mothers while pregnant and giving birth is less (Wati, 2014).

Age 25-36 months is toddler, at this age mothers are still worried about their children's health, so mothers still take their children to Posyandu to weigh and monitor the growth and development of their children (Fitri, 2015) ${ }^{19}$. This is the same as the results of Asdhany's study (2012), regarding the relationship of the level of maternal participation in Posyandu activities with the nutritional status of children under five, it was found that the majority of children who visited Posyandu were 24-59 months (71\%).

2. Gender

The results showed the majority of male child respondents were 204 people $(53.4 \%)$ Data from the Amplast Health Center in 2016, of the 8300 children under five (1-5 years) more male than female, namely as many as 4344 men and 3956 women, so that more children come to posyandu male sex man This is the same as the result of Handini's research $(2013)^{21}$, regarding the relationship of family income level with the nutritional status of children under five years old, it was found that the majority of respondents were male $(56.9 \%)$.

\section{Education}

The results showed the majority of maternal respondent education was high school as many as 325 people $(85.1 \%)$. This is the same as the results of Lestiawati's research (2018), regarding the relationship between the level of maternal participation in Posyandu and the nutritional status of children under five, also obtained the majority of respondents' education, namely high school education (70\%). The results of Nurhayati's research (2017); regarding the relationship of parental education with the nutritional status of children under five, found that there is a relationship between parental education and the nutritional status of children under five.

High school educated mothers believe in the importance of bringing children to visit Posyandu in monitoring growth, development, nutritional status, and the importance of health 
services (Maryunani, 2010) ${ }^{10}$. The results of this study found that the majority of respondents were high school-educated mothers with mothers working as housewives (IRT), so they had free time to bring their children to Posyandu.

\section{Profession}

The results showed that the majority of respondents' jobs were Housewives (IRT) as many as 347 people (90.8\%). This is the same as the result of Nurhayati's study (2017), concerning the relationship of the level of maternal participation in Posyandu activities with the nutritional status of children under five, it was found that the majority of respondents' jobs were not working $(83.9 \%)$.

Posyandu activities are carried out in the morning so that most mothers who visit Posyandu are not working. Working mothers are bound by working hours so that mothers cannot bring their children to the Posyandu on working hours. Mothers who do not work have more free time to pay attention to their children by bringing their children to Posyandu (Lestari, 2015).

\section{Visit to Posyandu}

The results showed that respondents who did not bring their children to visit Posyandu were 237 people (62\%) and those who routinely visited Posyandu were 145 people (38\%). In this study, more respondents of mothers did not bring their children to the posyandu due to several problems, namely the lack of health facilities in the posyandu, the lack of quality health services at the posyandu, and the lack of activities from the puskesmas so that mothers were not interested in coming to take the child to the posyandu. This is reinforced by Handayani's (2013) research on the relationship between the quality of posyandu health services and the frequency of visits of mothers of toddlers to posyandu, obtained $p$ value $(0.00)$. There is a relationship between the quality of health services for posyandu and the frequency of visits of mothers of toddlers to posyandu.

\section{Toddler Nutritional Status}

The results showed that respondents' nutritional status was good nutrition as many as 203 people $(53.1 \%)$. The results of this study showed that respondents who did not regularly visit the posyandu had good nutrition as many as 103 people (43.5\%), almost the same as those who regularly went to the posyandu as many as 100 people $(69.0 \%)$. Mothers who do not routinely go to the posyandu cause the child's body weight to not be monitored properly, so that children are still lacking in nutritional status and poor nutritional status. This can be prevented if the mother routinely goes to the posyandu because she will be given counseling related to maternal and child health by health workers from the Community Health Center, so as to increase the mother's understanding of the nutritional status, growth and development of her child.

7. Relationship between the Number of Posyandu Visits and the Nutritional Status of Children under Five (1-5 years)

The results showed that respondents who routinely visited Posyandu had good nutrition as many as 100 people $(69.0 \%)$ and respondents who did not routinely visit Posyandu had good nutrition as many as 103 people (43.5\%). Statistical test results obtained p value $(0.00)$ then Ho is rejected, so it can be concluded that there is a relationship between the number of posyandu visits with the nutritional status of children under five (1-5 years) ( $p$ value $<a)$.

This is reinforced by the results of Octavianis et al (2016) research, regarding the relationship of family activity in Posyandu activities with the nutritional status of children under five, it was found that there was a relationship between family activeness to Posyandu and nutritional status of children under five ( $p$ value 0.00). Dewi research (2017), about the relationship between the activity of mothers visiting Posyandu and the development of nutritional status of children aged 6-23 months, found that the activeness of maternal visits to 
posyandu also affects the nutritional status of children ( $\mathrm{p}$ value 0.02 ).

Mothers' participation must be increased in an effort to reduce the problem of malnutrition in children by visiting and weighing their toddlers to Posyandu every month.

Mother's routine in visiting posyandu will be very useful as monitoring body weight to determine the nutritional status of children by weighing weight every month so that they can detect the child's health status early, so that further intervention can be determined immediately. If the mother does not regularly visit the posyandu, the nutritional status of the child is not well monitored.

\section{Conclusion}

\subsection{Conclusion}

After conducting research on the relationship between the number of posyandu visits and the nutritional status of children under five (1-5 years), it is known that the majority of respondents studied were aged between $26-35$ years as many as 327 people (85.6\%). The majority of children respondents aged 25-36 months were 184 people (48.2\%) with male sex as many as 204 people $(53.4 \%)$. The majority of respondents with a high school education are 325 people $(85.1 \%)$ with 347 occupations as IRTs $(90.8 \%)$. Family income in the month $500,000-1,500,000$ as many as 235 people $(61.5 \%)$ with good nutrition children as many as $203(53.1 \%)$.

Respondents of mothers who did not bring their children to visit the posyandu were 237 people (62\%) and those who routinely visited the posyandu were 145 people (38\%). Respondents who routinely visited posyandu had good nutrition as many as 100 people $(69.0 \%)$ and respondents who did not routinely visit posyandu had good nutrition as many as 103 people (43.5\%). Statistical test results obtained p value $(0.00)$ then Ho is rejected, so it can be concluded there is a relationship between the number of posyandu visits with the nutritional status of children under five (1-5 years).

\subsection{Suggestion}

1. Development of Nursing

The results of this study are expected to add insight and knowledge about the relationship between posyandu visits and the nutritional status of children under five.

2. Integrated Healthcare Center

The results of this study are expected to be additional information for cadres that the posyandu can monitor the nutritional status of infants through routine weight weighing at the posyandu.

3. Public health center

The results of this study are expected to be information for health workers in the Puskesmas so that they can conduct training and counseling for posyandu cadres, so as to increase cadres' knowledge about health, Posyandu management properly, and monitoring children's nutritional status.

4. Public

The results of this study are expected to be information for the community, especially mothers who have toddlers to be more active in posyandu activities every month to monitor the nutritional status of children by weighing regularly so as to reduce the incidence of malnutrition.

5. Next Researcher

The results of this study are expected to be a material of information in conducting further research on posyandu and nutritional status of infants and can continue this research to 
further develop research in knowing posyandu visits to the development and growth of toddlers in terms of height based on children's age and weight based on height.

\section{References}

Adisasmito W. 2007. Faktor Risiko Diare Pada Bayi Dan Balita Di Indnesia: Systematic Review Penelitian Akademik. Makara, Kesehatan, Vol 11, No 1, Juni 20071-10.

Amin, M. A. S. 2020. Communication Activities in Mitoni Events in Layansari Village (Study of Communication Ethnography Regarding Communication Activities at the Mitoni Event in Layansari Village, Gandrungmangu District, Cilacap Regency in requesting the safety of Mother and Child). Budapest International Research and Critics InstituteJournal (BIRCI-Journal) (3): 1289-1296.

Astuti I, Rivqoh. 2010. Hubungan Pengetahuan Ibu tentang Posyandu dengan Keteraturan Ibu Mengunjungi Posyandu di Desa Cibeber Rw 14 Puskesmas Cibeber Cimahi Tahun 2010. J Kesehat Kartika.

Busri. 2017. Faktor Faktor yang Menyebabkan Rendahnya Peran Ibu Balita ke Posyandu Desa Sumber Datar Wilayah Kerja Puskesmas Keranji Tahun 2016. J Doppler Univ Pahlawan Tuanku Tambusai.

Dewi, A. B. F. K., Pujiastuti, and Fajar, I. Ilmu Gizi untuk Praktisi Kesehatan. Yogyakarta: Graha Ilmu; 2013.

Dinas Kesehatan Provinsi Sumatra Utara. Profil Kesehatan Sumatra Utara Tahun 2017. Profil Kesehat Sumatra Utara Tahun 2017. 2017;

Depkes, Adisasmito W, Bab I, Ilmiah KT, Tyas AC, Studi P, et al. Perpres RI Nomor 72 tahun 2012 tentang Sistem Kesehatan Nasional. Bul INFARKES Ed II. 2015;

Fallis A. Hubungan Keaktifan Keluarga Dalam Kegiatan Posyandu Dengan Status Gizi Balita di Desa Rancaekek Kulon Kecamatan Rancaekek. J Chem Inf Model. 2013;

G, W, A F. Peran Kelompok Bermain dalam Proses Sosialisasi Anak Usia Dini di Kecamatan Sukorejo Kabupaten Kendal Semarang. Digilib Unnes [Internet]. 2017; Available from: http://lib.unnes.ac.id

Handayani IK. Faktor - Faktor yang Mempengaruhi Partisipasi Ibu Membawa Balita ke Posyandu Tambun Baru Desa Pahlawan Setia Kecamatan Tarumajaya Bekasi Jawa Barat. Universitas Esa Unggul. 2013.

Handayani R. Faktor-Faktor yang Berhubungan dengan Status Gizi pada Anak Balita. J Endur. 2017 ;

I Ketut Swarjana S. Metodologi Penelitian Kesehatan - , MPH - Google Buku. CV Andi Offset. 2012.

Kemenkes R. Profil Kesehatan RI 2015. Profil Kesehatan Indonesia Tahun 2015. 2015.

Kementerian Kesehatan RI. Rencana Strategis Kementerian Kesehatan Republik Indonesia Tahun 2015-2019 Keputusan Menteri Kesehatan Republik Indonesia Nomor HK.02.02/MENKES/52/2015. kementerian Kesehatan RI. 2015.

Kurniasari AD, Nurhayati F. Hubungan antara Tingkat Pendidikan, Pekerjaan dan Pendapatan Orang Tua dengan Status Gizi pada Siswa SD Hangtuah 6 Surabaya. J Pendidik Olahraga dan Kesehat. 2017;

Maryuani A. Ilmu Kesehatan Anak Dalam Kebidanan. Ilmu Kesehat Anak Dalam Kebidanan Jakarta Trans Info Media. 2010;

Muharry, A., Kumalasari, I., and Dewi, E. R. Faktor yang Mempengaruhi Status Gizi Balita di Puskesmas Nelayan Kota Cirebon. Ji-Kes (Jurnal Ilmu Kesehatan). 2017;

Nurdin N, Ediana D, Dwi Martya Ningsih NS. Faktor-Faktor yang Berhubungan dengan Partisipasi Ibu Balita ke Posyandu di Jorong Tarantang. J Endur. 2019; 
Oktavianis. Faktor-Faktor yang Berhubungan Dengan Status Gizi Pada Balita di Puskesmas Lubuk Kilangan. J Hum Care. 2016;

Profil kesehatan provinsi jawa tengah tahun 2016. Dinkes Jateng. Dinas Kesehat Provinsi Jawa Teng. 2016;

Pusat Data dan Informasi Kemenkes RI. Infodatin: Situasi Balita Pendek. ACM SIGAPL APL Quote Quad. 2016;

Putri RF, Sulastri D, Lestari Y. Faktor-Faktor yang Berhubungan dengan Status Gizi Anak Balita di Wilayah Kerja Puskesmas Nanggalo Padang. J Kesehat Andalas. 2015;

Republik Indonesia. Rencana Pembangunan Jangka Menengah Nasional 2015-2019. Rencana Pembang Jangka Menengah Nas 2015-2019. 2015;

Rildayani, Nurjannah, Saputra, I., Yeni, C. M., and Usman, S. 2020. The Effect of the Comprehensive Midwifery Care Model with the One Student One Client (OSOC) Approach to Birth Outcomes in North Aceh Regency. Budapest International Research and Critics Institute-Journal (BIRCI-Journal) (3): 1676-1682.

Rizal, M., and Djannah, F. 2020. Impact of Violence against Children in the Family Related To Law Number 23 Year 2004 Concerning Deletion of Violence in Household. Budapest International Research and Critics Institute-Journal (BIRCI-Journal) (3): 348-358WHO. Reducing Stunting in Children: Equity Considerations for Achieving the Global Nutrition Targets 2025. WHO Library Cataloguing-in-Publication Data. 2018.

SDKI. Laporan Pendahuluan Survey Demografi dan Kesehatan Indonesia 2017. In: Survey Demografi dan Kesehatan Indonesia 2017. 2017.

Wati, I. K. Faktor-Faktor yang Berhubungan dengan Minat Ibu Terhadap Kunjungan ke Posyandu di Kelurahan Kembangarum Kota Semarang. J Stikes Ngudi Waluyo. 2014;

Yuliansyah A, Lestiawati E. 2018. Analisis Faktor yang Berhubungan dengan Partisipasi Ibu Membawa Anaknya Ke Posyandu Kelurahan Kricak Wilayah Kerja Puskesmas Tegalrejo Yogyakarta. J Keperawatan Respati Yogyakarta. 